DOI: $10.11649 /$ abs.2018.013

\author{
Aliaksandr Smalianchuk \\ Institute of Slavic Studies, Polish Academy of Sciences \\ Warsaw \\ aleksander.smalianchuk@ispan.waw.pl
}

\title{
Oral history in Belarus: Present state and development trends
}

As it is today, oral history is a rather extended branch of humanities scholarship and social studies. Its subject is the individual life experience of a person, his/her memory (Kurkowska-Budzan, 2003, pp. 176-186), and its main research method is the interview. Accordingly, oral history is related to such humanities and social studies as sociology, ethnology, ethnography and cultural anthropology. In the absence of a uniform definition of oral history, the majority of scholars usually view it in terms of its main components, including audio and video recording of an interview, its archivisation (creation of a historical source), analysis of the obtained historical sources and presentation of the results of oral historical research (Kurkowska-Budzan, 2001, pp. 10-11; Кiсь, 2007, pp. 13-14).

Oral history has been recognised as an academic discipline in most countries. In the United States and Western Europe, it has even celebrated its 60th anniversary. In Belarus, however, an interest in this branch of scholarship and prospects for its development emerged only in the early 1990s.

Nevertheless, oral history has undeniable importance for the development of modern Belarusian academia. More and more often, its methods are applied as a tool in research on social memory, identity and mentality. Apart from this, oral history has a great potential as a platform for interdisciplinary co-operation between scholars of various social sciences and humanities. 
In the first place, the great potential of this research lies in the field of the "battles for history" which started in Belarusian society immediately after the collapse of the Soviet Union. The interpretations of the events of "the Belarusian twentieth century" vary greatly, mostly conflicting with each other. In these discussions, oral history offers a view that is a real alternative to the official historical policy, still based on the Soviet ideological clichés.

It must be noted that even today Belarusian historians still confront problems well known to those who began their academic career in the Soviet times: a lack of freedom in historical research, the ideological dictate of government officials, the inaccessibility of certain archives or archival sources.

In fact, the whole development of oral history in Belarus stems from the activities of several non-governmental academic and public organisations and research centres. Observing the thirty years of oral history's presence in the scholarly and cultural life of Belarus, we can highlight some stages in its development, as well as evaluate its future prospects.

What has been the way of oral history in Belarus? What characterises its current state? What perspectives does it have as an academic discipline in Belarus?

To answer these questions, we must consider the subject matter and methods of oral historical research, the researchers' approaches to the analysis of the obtained sources, as well as the dynamics of the institutionalisation of this trend.

The end of the 1980s and the early 1990s in Belarus were marked by a considerable public interest in the country's past. Belarusian society was discovering the fascination and beauty of national history. The first attempts at oral historical studies, which were made mostly by researchers of Belarusian literature, journalists and local historians, introduced readers to the unknown facts from the life of famous Belarusians and often presented a "non-Soviet" vision of the past.

In the 1990s and early 2000s the true monopolists in the field of oral history in Belarus were historians and local ethnographers. This period was characterised by an active search for topics and approaches, as well as a growing interest in the method of oral history, thanks to the enthusiasm of individual researchers and teachers. In this period oral memories came to be perceived as a new historical source alternative to traditional approach. Moreover, this new source proved helpful to historical biographical studies, as well as to the study of social, ethnic, religious, professional and other groups (Грінченко, Реброва, \& Романова, 2014).

Oral history first attracted public attention in 1988, when archaeologists discovered mass burials of victims of Stalinist terror in Kurapaty near Minsk. The archaeologist Zianon Pazniak not only conducted excavations, but also collected oral accounts of elderly residents of the surrounding area. His recordings confirmed the crimes of Stalin's regime. Zianon Pazniak and Iaŭhen Shmyhalioŭ published an article "Kurapaty - daroha s'mertsi" (Kurapaty, the Road of Death) in the newspaper Litaratura 
$i$ mastactva (Literature and Art), where they referred to their records of oral sources (Пазьняк \& Шмыгалёў, 1988; Пазьняк, Шмыгалёў, Крывальцэвіч, \& Іоў, 1994, pp. 10-26). The publication received an overwhelming public response, which considerably forwarded the process of Belarus' parting from her communist past.

The beginning of oral history as a research method in Belarus is associated with the name of Mikalaĭ Ulashchyk (1906-1986), a pre-eminent figure of national historiography. His historical-ethnographic article published in 1989, "Byla takaia vioska" (There Was a Village) (Улашчык, 1989), was one of the first historical works applying the method of oral history. In this essay, which he wrote in the 1970s, Ulashchyk widely used oral sources - stories told by his relatives during his childhood times and preserved in his memory. The result was a detailed outline of the socio-economic development and daily life of Vitskaŭshchyna village in the Minsk region at the turn of the nineteenth and twentieth centuries. Although many Belarusian researchers paid attention to this work, only a few of them ventured to leave their offices and plunge into the atmosphere of the "living archives".

One of the first to do this was the historian Nina Stuzhinskaia. In the late 1990s, she headed a project called "The History Absent in Textbooks". Young researchers under her leadership recorded memories of people repressed during the Stalinist terror.

The project named "The Nearby History" (2000-2003) also contributed to the public promotion of oral history. Initiated by the association called Dyiaryiush (The Diary), it included an essay contest for schoolchildren on such topics as "My family tree", "The fate of my family in the twentieth century", "Daily life in Belarus in 1945-1965", etc.

Yet the real pioneers in the field of oral history in Belarus were the members of the Belarusian Historical Society in Poland. In the second half of the 1990s, they began collecting oral memories of World War I refugees who after the war returned home to their native region of Podlasie. In 2000, an anthology of memoirs, Bezhanstva 1915 hoda (The Refugees of 1915), was published in Białystok. The volume contained newly recorded oral testimonies as well as a reprint of those previously published in the Belarusian weekly Niva (The Land) issued in Białystok (Луба, 2000). The following year (2001) brought another anthology, U novaĭ Aĭchyne (In the New Patria), devoted to the daily life of Belarusians in Białystok in the interwar period (Луба, 2001). Finally, there came the third book, Pakalenne vainy (The War Generation, 2003), which contained oral memories of everyday life of Belarusians in Białystok during the Second World War (Луба, 2003). The preface to the whole collection was written by the renowned historian Eugeniusz Mironowicz.

The volumes published in Białystok attracted public attention. For the first time the interview method was systematically used in this type of research, and oral memories acquired documentary status. But there were also some shortcomings. Unfortunately, the leaders of the project did not consider it necessary to acquaint the reader with 
the theoretical and methodological aspects of the study: they did not describe the research method, did not characterise research teams and did not include the questionnaires; the accounts were published in the literary Belarusian language (i.e. not in the original version), and so on. Nevertheless, it was thanks to these works that many Belarusian scholars became acquainted with a new branch of historical research.

An important step in the further promotion of oral history was the article "Oral History" by the British researcher Gwyn Prins, ${ }^{1}$ published in translation by Belaruski histarychny ahliad (The Belarusian Historical Review, edited by Henadz Sahanovich) in 2000 (Прынз, 2000, pp. 416-447). The author pointed out the innovative nature of oral history, fought off criticism from the traditional, documentary historians and justified the right of this new direction in historiography to academic status.

The late 1990s marked the beginning of oral history field studies led by Aliaksandr Smalianchuk. The first expeditions were devoted to recording the memories concering the life and economic activities of Roman Skirmunt, a prominent Belarusian politician, patriot, head of the government of the Belarusian National Republic (July 1918). The research covered the 1920 and 1930s, when Skirmunt retired from the Belarusian movement and lived at his estate of Parecha near Pinsk. The publication in the Spadchyna (The Heritage) journal (2000) was the first attempt at interpreting oral memories concerning Roman Skirmunt (Смалянчук \& Сідлярэвіч, 2000, pp. 96-103). It demonstrated the significance of oral history for the development of historical biographical studies and the study of the history of Belarusian towns and villages. The result of the following expeditions was a series of publications devoted, firstly, to Princess Maria Magdalena Radzivil (Radziwiłł), one of the founders of the Belarusian and Lithuanian national movements of the early twentieth century; secondly, to the reflection on the events of the Second World War in the memory of Belarusian villagers, and to some other themes.

This early stage of the development of oral history in Belarus was marked mostly with a positivist attitude to oral historical sources. Researchers emphasised their accuracy, the capacity of human memory to store oral information for generations, and their similarity to traditional written sources. Oral history was perceived as a real window into the past, which could work even without any comment by a professional historian. Memory was treated as a kind of "living archives", and the narratives of the respondents were perceived as a fact of history.

At this stage, the topics that prevailed were those banned during the Soviet period. In particular, the themes of Stalinist repressions and anti-Soviet resistance (Nina Stuzhinskaia, Zianon Pazniak), the fate of the Belarusian postwar emigrants (Liavon Iurèvich), biographical studies related to the figures purposefully erased from

1 Peter Burke (ed.), New Perspectives on Historical Writing, Cambridge: Polity, 1992, pp. 114-139. 
Belarusian history, the daily life under the German occupation during the Second World War, and so on.

A departure from this somewhat naïve oral historical positivism began in the mid-2000 s. The optimism of the 1990s gave way to critical thinking about the ambivalent nature of the memory phenomenon, the role of narration in the creation of a separate reality of individual consciousness, reflections upon the uncertainty of the boundaries between "the fact" and its perception by an individual. Researchers began to realise that oral memories do not contain "a pure fact", and that they are dealing with an individual or collective interpretation of the events, in which it is impossible to separate a fact of history from the mind of the respondent. There has also come an understanding that memories are subject to influences of individual experience and social conditions. It has become clear that the memory of an individual is in constant interaction with common cultural memory. The very research method of oral history, i.e. the interview, has also come under criticism. It has been realised that the personality and professional interests of the interviewer remain ever present in every oral historical source that came to life in the course of his/her dialogue with the respondent.

These changes largely stemmed from the contacts between Belarusian researchers and their colleagues from other countries, as well as from taking into consideration the experience of ethnographers, anthropologists and linguists in collecting and analysing oral memories.

An important part in these changes was played by the educational and research programme called "The Borderlands of Belarus: History, Culture, Language" (supervised by Elżbieta Smułkowa), organised by the International School of Humanities at the Centre for Studies of Ancient Traditions in Poland and Central-Eastern Europe, Warsaw University (MSH OBTA UW). Running from 2001 to 2006, the programme became a real school of oral history for the majority of modern Belarusian "oral historians".

The project aimed to collect and analyse oral memories in the Belarusian-Polish, Belarusian-Ukrainian and Belarusian-Russian borderland areas. Several groups of specialists in different disciplines worked on its implememtation, including ethnographers, historians, linguists - who were the main force - and cultural anthropologists. The project also included a number of seminars and a conference (2005).

The most important result was a collection of articles edited by Elżbieta Smułkowa and Anna Engelking, which accumulated the field experience of interdisciplinary communication (Smułkowa \& Engelking, 2007). The volume proposed a range of theoretical frameworks and adapted certain theoretical categories for oral historical research. For example, anthropological and linguistic ones - for oral history (the categories of "borderland", "us" vs "them" and others); the method of oral history - for linguistic and anthropological analysis.

So far, this has been the most successful practice of interdisciplinary research related to oral history. In addition, "The Borderlands of Belarus: History, Culture, 
Language" project helped to uphold European academic standards in the preparation and analysis of materials from oral history expeditions.

We should also mention the opening of the History Workshop in Minsk (headed by Kuzma Kozak) in 2002, founded by the Dortmund Educational Centre, the Johannes Rau International Educational Centre in Minsk and the Union of Belarusian Jewish Public Associations and Communities. The main objective of this Belarusian-German project was to develop and implement historical education programmes and to support new trends in the study of military history and occupation of Belarus in Belarusian and German historiography. For example, members of the History Workshop collected and published testimonies, also oral, of Minsk ghetto prisoners.

Of great significance was the participation of Belarusian researchers in the project of collecting oral memories about the fate of the so-called Ostarbeiters (2005-2006), who had been taken to Germany as forced labor during the Second World War. This project was initiated by the Memory and Future fund, which supported research and educational projects devoted to the memory of the victims of German national socialism. The project involved researchers from twenty-four European countries, the United States, Israel and South Africa. It was co-ordinated by the Institute of History and Biography at the Distance University of Hagen (headed by Alexander von Plato). Under the project, 550 audio and video interviews were recorded, including forty in Belarus. Belarusian participants had the opportunity to work together with experienced German researchers, and for some of them it was the beginning of research involvement in the field of oral history (Пастушенко, 2008, p. 645).

One of the latest examples of a fruitful Belarusian-German co-operation in the field of oral history was the project "A Living History of My Land" (2013-2014), conducted by the Deutscher Volkshochschul-Verband e.V. association (Germany), together with a number of Belarusian state and non-governmental organisations. An active participant in that project was Iryna Kashtalian (Minsk), the co-ordinator of the online project Belarusian Archives of Oral History. An important part of the project was the popularisation of oral history among the residents of Belarusian villages. Iryna Kashtalian and the German researcher Imke Hansen prepared methodological advice promoting the use of oral history technique in the study of local history and culture (Хансен \& Кашталян, 2014, pp. 80-126).

We should also note the Belarusian-Ukrainian project "Transformation of Everyday Adaptive Practices: Soviet and Post-Soviet Periods. Belarus, Ukraine" (Institute of History of the National Academy of Sciences of Belarus, Belarusian State University, Odessa National University), among whose active participants were the Belarusian researchers Iryna Ramanava and Iryna Makhoŭskaia. They were also involved in the Belarusian-Russian project "Transformation of the Everyday Life of the Soviet People between the 1930s and 1950s" (Institute of History of the National 
Academy of Sciences of Belarus, Belarusian State University, Centre for Oral History of Petrozavodsk State University).

One result of this project was the publication of articles devoted to the adaptation practices of the inhabitants of small West-Belarusian towns in the 1920s and 1930s and of the former GULAG prisoners after their return home (Маховская, 2008, pp. 61-73; Романова, 2008, pp. 31-51), as well as a number of oral accounts published in the volume Ustnaia istoriia $v$ Karelii (Oral History in Karelia, 2008). The latter were an example of how to successfully reconstruct the past using oral records in the form of a thematic collection, and how to publish them with minimum comments from, or interpretation by, the investigator (Такала, Голубев, Романова, \& Маховская, 2008, pp. 86-227).

One of the most significant works of Belarusian oral history is Ramanava and Makhoŭskaia's study entitled Mir: Historyia miastecchka, shto raskazali iaho zhykhary (Mir: A History of the Town as Told by Its Citizens) (Раманава \& Махоўская, 2009). The researchers, together with the students of the Belarusian State University, for several years recorded the accounts of the townsfolk of Mir, Hrodna region. The authors focus on the daily life of the town and the castle in the interwar period (when Mir was in Poland), in the period of the so-called "First Soviets" (1939-1941) and during the German occupation (1941-1944). The researchers used the technique of themed montage of fragments from stories of different respondents, complemented with certain biographical episodes of Mir inhabitants, in order to construct a kind of collective story about their everyday life. As the Jews had left the town, it was more difficult to restore the Jewish part of Mir's history, and their life was recollected by their former neighbours - Belarusians, Poles and Tatars. The authors have tried to compensate for the one-sided view using the epistolary heritage of Mir's Jews and including fragments of their published memoirs.

This book is an example of a cross-method reconstruction of history based on oral sources, commonly applied in modern Belarusian historiography. The oral evidence becomes a source and a basis for the construction of the argument about the behaviours of people or the nature of the events and phenomena in the past. A special feature of this approach is that quotations from interviews are mixed with information from other sources or with known facts.

Between 2006 and 2011, the Institute for Historical Research on Belarus (headed by Aliaksandr Smalianchuk) at the European Humanities University in Vilnius (EHU) conducted a project called "The Twentieth Century in the Memory of Belarusians". During this time, five expeditions of EHU academic teachers and students worked in the Pinsk district of the Brest region (2006), Braslaŭ district of the Vitsebsk region (2007), Slonim district of the Hrodna region (2008), Mazyr district of the Homel region, Stolin and Ivanava districts of the Brest region (2009), Pastavy district of the Vitsebsk region and Miadzel district, Minsk region (2010). The research focused 
on the life on the territory of Belarus occupied by the German army in the summer of 1941, adaptation practices and the fight against the invaders.

The activity of the Institute for Historical Research on Belarus contributed to improving the methodology of collecting and analysing oral sources, including the preparation of methodological advice and questionnaires for interviews, and the expansion of research topics, which began to cover issues of both individual and collective memory, as well as mentality issues (Смалянчук, 2013, pp. 138-153). This also meant solving certain educational problems and contributed to the popularisation of oral history.

As for popularisation, it is important to note the role of the journal Homo Historicus: The Annual of Anthropological History (edited by Aliaksandr Smalianchuk), which has been publishing materials on oral history in almost every volume. Usually, they present the results of different studies. Among the most important we should mention the articles by Irena Šutinienè "Druhaia susvetnaia vaĭna ŭ kalektyŭnaĭ pamiatsi zhykharoŭ Litvy" (World War II in the Lithuanians' Collective Memory) (Шуцінене, 2008, pp. 411-425), Volha Shatalava "Tseni vaĭny: Palitsěskiia i partyzany ŭ pamiatsi nasel'nitstva belaruskaĭ vioski" (The Shadows of the War: The Policemen and the Partizans in the Belarusian Villagers' memory) (Шаталава, 2008, pp. 384-389), and Anna Engelking "Pamizh panam i zhydom: Zaŭvahi pra strukturu idèntychnastsi belaruskikh kalhasnikaŭ na rubiazhy XX-XXI st." (Between the Master and the Jew: Remarks on Belarusian Collective Farm Workers' Identity at the Turn of the 20th and 21st Centuries) (Энгелькінг, 2012, pp. 89-117).

Analytical articles extensively based on oral sources have also been published by such authors as Natalia Hardzienka (Minsk), who studies the Belarusian emigration (Гардзіенка, 2004, 2010); Alesia Belanovich-Petz, researching the "Ostarbeiters" (Белановіч, Верамейчык, 2011); Iryna Kashtalian (Minsk), investigating the everyday life in postwar BSSR (Кашталян, 2013, pp. 134-142, 2015, pp. 244-249); and Tatsiana Kasataia (Hrodna), who uses this method in the research on the Evangelical Christian Baptist communities in postwar Belarus, as well as in the reconstruction of the history of Hrodna in the twentieth century. The latter issue is also the subject of research conducted by Andrëĭ Vashkevich (Hrodna) (Касатая, 2015, pp. 233-243; Касатая \& Вашкевіч, 2015, pp. 105-114). Uladzimir Valodzin (Minsk), in turn, is interested in the protest strategy of the Belarusian youth in the 1960 and 1970s (Валодзін, 2008, 2014), and Anatol Trafimchyk's (Minsk) - in the everyday village life in Western Belarus in the 1920 and 1930s, and the image of the "First Soviets" of 1939-1940 in the memory of Belarusian witnesses of the Second World War (Трафімчык, 2015, pp. 95-104).

Considering the issue of institutionalisation of oral history as an academic discipline, we should note the activity of the Belarusian European Humanities University (EHU), which since 2006 has been a university-in-exile: under the decision of Belarusian authorities it was closed (in Minsk), but resumed its activities in Vilnius. 
From 2007 to 2011 Aliaksandr Smalianchuk taught a course entitled Oral History: Theory and Practice within the EHU Master's programme called Protection and Interpretation of Cultural Heritage. As part of this course, students conducted independent research on oral history, including such topics as: "Frantsishak Bahushevich in the memory of Svirany village residents", "The Uprising of 1939 in the memory of the residents of the town of Skidzel", "The nonconformists of the Soviet Minsk", "The town of Pukhavichy and the village of Blon in the interwar period", "Power in the views of Belarusian village residents" (based on the Braslaŭ Expedition 2007). The first EHU Master's thesis in the field of oral history - "Vitsebsk of the 1920s-1940s in oral history" by Aliaksandr Minin - was written in 2009.

It also should be noted that in 2014-2015 lectures in oral history were held at two Minsk-based institutions of informal education, The Belarusian Collegium and The Flying University.

Unfortunately, oral history practically does not exist in state educational institutions in Belarus; there are no special courses in oral history in the curriculum of historical faculties of Belarusian universities. Attempts to create laboratories or centres of oral history at the Belarusian State University and the State University of Hrodna were unsuccessful. We have to admit that today oral history has no chance of institutionalisation in public institutions of higher education in Belarus.

Meanwhile, in recent years the issues of oral history have been present in many conferences, particularly the International Congresses of Belarusian Studies, held annually in Kaunas since 2011 on the initiative of the Institute of Political Studies "Political Sphere", and in other conferences of this Institute. In November 2014 an international scholarly conference Oral History: Theory and Practice was held at the Brest University. However, the most significant event in the development of this discipline in Belarus was the conference organised by The Belarusian Archives of Oral History (2014), devoted to the 75th anniversary of the outbreak of the Second World War and the reunification of Belarusian lands within the Stalinist BSSR.

It should be noted that the online project called The Belarusian Archives of Oral History (BAOH) began in 2011 and since then has become a real centre for the development of oral history in the country. As it is today, its contribution to the institutionalisation of this area of historical and interdisciplinary research is largely fundamental.

The BAOH's main objectives include the collection, preservation and popularisation of documents of oral history, as well as the methodological and scholarly development of this field. The initiative to create a data base storing the electronic version of these documents came from Iryna Kashtalian, who received active support from Anatol Vialiki, Volha Ivanova and the members of the association Historyka. In 2011-2012 the archives were designed using the modern techniques of archival practice. 
The first task to be solved in the course of the project was that of collecting the data. This, in fact, is the task of preserving the memory of participants and witnesses of historical events. Some oral accounts were gathered by the Archives team in the course of field expeditions and individual interviews; others came from the collections of oral material gathered by other researchers, mainly historians, journalists and ethnographers who recorded oral memories for their research. For instance, the Archives have received for permanent storage the collections of Aliaksandr Smalianchuk (2002-2011), Safroniǔ Zhloba and Iryna Charniakevich (the late 1990s), Nina Stuzhynskaia (the late 1990s), Natallia Hardzienka (20032005), Iryna Ramanava (2003-2004), Uladzimir Valodzin (2007), Iryna Kashtalian (2008-2009). The subjects of these oral memories vary from the history of Stalinist repressions to daily life, from the Belarusian emigration to the "Ostarbeiters", from the history of Belarusian cities, towns and villages to ethnographic records and even the history of Minsk hippies.

By the late summer of 2017, the Archives had fifty collections containing about 1,200 interviews and over 5,000 documents; their total size was approximately 3.0 terabytes. All the materials, including textual versions (transcripts) of a large part of the recordings, are available on the Internet (www.nashapamiac.org). Their collection and storage is based on the methodological approaches of oral history and technical principles commonly adopted in archival practice.

The scholars involved in the project work on a number of issues which are important for the twentieth-century Belarusian history, but remain almost unexplored for some ideological or political reasons. In particular, "The Year 1939 in the Memory of Belarusians" (coordinator A. Smalianchuk), "The Post-war Famine in Belarus" (coordinator I. Kashtalian), "The History of Hrodna and Minsk in the Twentieth Century in the Memories of their Residents" (coordinators I. Satsukevich and T. Kasataia), "The Belarusian Ostarbeiters" (coordinator A. Belanovich-Petz), "The Chernobyl Accident and its Consequences in the Memory of the Inhabitants of Belarus" (coordinator U. Valodzin), and "Collectivisation in Western Belarus, 1948-1952" (coordinator A. Smalianchuk).

The Belarusian Archives of Oral History regularly hold conferences and seminars attended by Belarusian and foreign experts in the field of oral history. In 2013, the $\mathrm{BAOH}$ hosted Imke Hansen from the Institute of Contemporary History (Berlin), and in 2015 - Alexander von Plato from the Open University of Hagen. The Archives cooperate with Belarusian and international institutions specialising in the field of oral history, such as the association Dyiaryiush (Belarus), the Karta Centre (Poland), the Online-Archiv "Zwangsarbeit 1939-1945" (Germany) and others.

The $\mathrm{BAOH}$ is not only a repository of oral sources, but also a scholarly and educational platform that has the potential to bring together the researchers of oral history and develop methodological advice. With a view to promoting the method 
of oral history, it holds trainings for teachers, journalists and anyone interested in this discipline.

One of the major popularising activities of the project was the contest for schoolchildren called "The year 1939 in the Memory of Belarusians". In the course of work on the contest, the Archives prepared a methodology handbook for the collection and processing of interviews, and some methodological recommendations for teachers, concerning the teaching of this subject in Belarusian secondary schools. Another contest in oral history for students began in 2015; it was devoted to the problem of the Chernobyl disaster and its consequences.

A turning point in the development of The Belarusian Archives of Oral History was the conference entitled September 1939 in the Historical Tradition and Oral History, held in Minsk in September 2014. Apart from the historical topics concerning not only the events of autumn 1939, but also many other important and unexplored problems of the national history of the twentieth century, the participants raised issues of development of oral history in Belarus.

The conference included reports prepared on the basis of archival materials, as well as those based on oral history sources. In particular, the use of the latter allowed to conclude that the events of the autumn of 1939 - which contributed to the unification of Belarusian lands within the Bielarusian SSR, but also marked the beginning of the Second World War - exist as two opposite places of memory in the recollections of contemporary Belarusians. One remains a symbol of the victory of Belarusians, though achieved largely as a result of Stalinist Soviet policy, and the other is a symbol of the tragedy, a reminder of the beginning of the war. The Polish historian Jan Jerzy Milewski (Białystok) described the clash of Polish, Belarusian and Jewish memories in the interpretation of the events of 17 September 1939. Volha Ivanova (Minsk) dealt with the images of "the Easterner" and "the Westerner" and the issue of the borderline. The paper "Important Dates in the Biographical Narrative" by the ethnologist Iryna Makhoŭskaia (Minsk) focused on the problems of the analysis of oral historical sources. The sociologist Aliakseĭ Lastoŭski (Minsk) drew attention to some specific features of the interview method, and so on.

An important part of the conference was a discussion entitled "Oral history in Belarus: Prospects for interdisciplinary interaction” (Смалянчук, 2015). The main debaters were scholars who represented history (Aliaksandar Smalianchuk and Iryna Kashtalian), sociology (Tatsiana Vadalazhskaia and Aliakseí Lastoŭski), archives (Volha Ivanova) and anthropology (Iryna Makhoŭskaia). It was the first ever public discussion on the status and prospects of oral history as a platform of interdisciplinary research held in Belarus.

In April 2016 The Belarusian Archives of Oral History organised an international conference The Chernobyl Disaster and Society: Thirty Years After the Catastrophe. It was also on this occasion that considerable attention was devoted to oral history, or 
rather the collective memory of Belarusians and Ukrainians of the Chernobyl disaster from the perspective of oral history (Смалянчук, 2017).

An international conference Soviet Repressions in Historical Research and Collective Memory was held in Minsk in November 2017. About forty participants from Belarus, Poland, Ukraine and Russia presented the results of their studies concerning this issue. The initiator and main organiser of the conference was the online project Belarusian Oral History Archives (headed by Iryna Kashtalian). The initiative was supported by the Polish Institute in Minsk, the Institute of Slavic Studies of the Polish Academy of Sciences (Warsaw) and the Flying University (Minsk). The issue of oral memories as the source of historical research was discussed in the contributions of the Belarusian historian Volha Ivanova, and Ukrainian ethnographers and historians Alla Dmitrenko and Vital Ivanchyshen.

In Belarus, oral history has become the subject of interest not only on the part of historians but also scholars of different social sciences and humanities. This interest stimulates discussions involving an analysis of its academic direction, which makes historians more critically evaluate the results of their research on oral history. Belarusian discussions about oral history are not unique. The debate about the academic status of the discipline, the verification of sources of oral origin, the methods of analysis and forms of presentation of the results of oral historical research is relevant for Western European scholarship.

As it is today, two basic approaches to oral history have formed in Belarus. The first one is focused on the reconstruction (or construction) of the past on the basis of oral memories of eyewitnesses of historical events. This task is urgent, both because of limited documentary historical sources of the traditional type, and in connection with the historical policy of the state, based on a combination of the ideological postulates of "West-Russianism" of the early twentieth century and the approaches of Soviet historiography.

According to the definition proposed by the Polish historian Piotr Filipkowski, interest in historical facts makes it possible to talk about the historical perspective of oral history (Filipkowski, 2010, p. 22). The second approach, increasingly more present in Belarus, views oral history as a tool in the study of social memory and identity (ethnic, social, historical, gender, etc.). In this case, the researcher focuses on what respondents say and how they say it, as well as on how they view the events and what meaning they attach to them. In this situation, according Filipkowski, we can speak of a sociological perspective (Filipkowski, 2010, p. 22).

Historians come to an understanding that oral memories as a specific phenomenon of memory may contain errors, inaccuracies, lies and so on. But this "subjectivity" is also a matter of history. We have to agree with the Italian researcher Alessandro Portelli that false oral sources do not exist, that narration errors often say more than a factual, accurate description. In his view, the value of oral sources often lies not in 
their accuracy, but rather in their deviation from the facts when fantasy, imagination, symbols come into play (Портелли, 2003, p. 41).

Of course, much depends on the tasks set by the researcher. But it is also obvious that today in Belarus oral historical studies are in the process of going beyond factual analysis and descriptiveness. It is increasingly more often that oral history is used by researches as a means to understand the person. It is gradually turning into a tool of studying the multidimensionality of human life and experience.

As a result, oral history creates great opportunities for scholars, since it does not have strict methodological limitations and is located at the intersection of different social disciplines and humanities - history, sociology, anthropology, psychology and others. The development of its own methodology is a distant prospect, as theoretical works on oral history still do not match the level of other disciplines. Volha Ivanova observes that the way out of this situation involves "the use of the existing frameworks and methodologies established by anthropologists, linguists, sociologists, psychologists" (Смалянчук, 2015). It should be noted that the use of a wider range of methodological works of other disciplines of humanities has become a feature of Belarusian oral history.

In the absence of its own categories and methods, oral history has a marginal position among humanities. At the same time, however, this situation makes it open to interdisciplinarity. Aliakseí Lastoŭski notes that "the supermarginal status of oral history in Belarus turns it into a kind of 'live missile', which can fly in any direction" (Смалянчук, 2015, p. 270).

The subjects of Belarusian studies in the field of oral history are determined by modern historical policy. Priority is given to topics that did not receive attention or were banned for political reasons.

The formation of principles of oral history and its institutionalisation take place mainly outside the public educational system, yet the process continues. It is associated primarily with non-governmental academic and public organisations.

Scepticism about oral history stems not only from its marginal position among scholarly disciplines. Verification of oral sources remains essential for researchers working within historical discourse. The experience of those involved in the online project Belarusian Archives of Oral History provides a certain model for Belarusian scholars in this respect.

In their practice, the most advanced procedure of creating oral sources involves a biographical interview with special thematic blocks. In addition, supporting documents are created that make it possible to analyse the interview by persons who did not participate in it. One of the main documents is an interview protocol, which records all its characteristic features and the interviewer's self-reflection immediately after the interview. A profile of the respondent is also included. As Iryna Kashtalian puts it: "At first, the source is created, then processed and only after that you can reflect 
on it. Simultaneously, the basis of usual archival records is provided" (Смалянчук, 2015, p. 266).

Importantly, the current state of oral history in Belarus is also characterised by the development of international projects and programmes. We can talk about a wide range of presentations of oral history projects and their results (articles and monographs, films, internet projects, radio broadcasts, etc.). In this respect, it is worth noting the division of oral history into "professional" and "amateur" versions, aided by the relative democracy of the methods and the availability of "living sources" of the discipline.

The prospects of oral history in Belarus are connected not only with its status as an academic discipline or area of interdisciplinary dialogue, but also as a specific scholarly practice. During the discussion in Minsk mentioned above, the sociologist Tatsiana Vadalazhskaia offered a view of oral history as "a certain intellectual practice" that one can learn and implement: "This exercise can enable a person to make a step towards history in general, out of the captivity of the textbook version of the past" (Смалянчук, 2015, p. 280).

Thus, over the last thirty years oral history in Belarus ceased to be a sort of "Western exotic" and turned into an important area of research and scholarly practice. However, under the current historical policy there is no chance for its recognition as an academic discipline. The immediate prospects for the development of oral history in Belarus are associated with the activities of non-governmental academic and public organisations, among which the most important part is now played by the online project Belarusian Archives of Oral History.

\section{Bibliography}

Filipkowski, P. (2010). Historia mówiona i wojna: Doświadczenie obozu koncentracyjnego $w$ perspektywie narracji biograficznych. Wrocław: Wydawnictwo Uniwersytetu Wrocławskiego.

Homo Historicus: The Annual of Anthropological History. (2008) (Vol. 1). Вільня: ЕГУ. Homo Historicus: The Annual of Anthropological History. (2012) (Vol. 3). Вільня: ЕГУ.

Kurkowska-Budzan, M. (2003). Historia zwykłych ludzi: Współczesna angielska historiografia dziejów społecznych. Kraków: Towarzystwo Wydawnicze Historia Iagellonica.

Kurkowska-Budzan, M. (2011). Informator, świadek historii, narrator - kilka wątków epistemologicznych i etycznych oral history. Wrocławski Rocznik Historii Mówionej, 1, 9-34. https://doi.org/10.26774/wrhm.5

Smułkowa, E., \& Engelking, A. (Eds.). (2007). Pogranicza Białorusi w perspektywie interdyscyplinarnej. Warszawa: DiG.

Белановіч, А., \& Верамейчык, Г. (2011). Парламент памяці: Гісторыі беларускіх “остарбайтараў”. Мінск: Міжнароднае грамадскае аб’яднанне “Адукацыя без межаў”. 
Валодзін, У. (2008). Першае пакаленне менскіх “хіппі” (другая палова 1960-х - першай палова 1970-х гг.). Зялёны край, 2008(2).

Валодзін, У. (2014). Калектыцуны зварот студэнтай-філосафаў 1981 г. Менск.

Гардзіенка, Н. (2004). Беларусы ў Аўстраліі: Да гісторыі дыяспары. Мінск: Медысонт.

Гардзіенка, Н. (2010). Беларусы ў Вялікабрытаніi. Мінск: Згуртаванне беларусаў свету Бацькаўшчына.

Грінченко, Г., Реброва, I. , \& Романова, I. (2014, October 30). Усна історія в пострадянських дослідницьких практиках. Украіна модерна. Retrieved August 26, 2015, from http:// uamoderna.com/md/grinchenko-rebrova-romanova-oh

Касатая, Т. (2015). Вусная гісторыя ў даследаванні евангельскіх хрысціян-баптыстаў у БССР. In А. Смалянчук (Еd.), Восень 1939 г. у гістарычнай традыцы і вуснай гісторыі. Мінск: Выдавец Зміцер Колас.

Касатая, Т., \& Вашкевіч, А. (2015). Вайна і мір 1939-1940 гг. ва ўспамінах жыхароў Гродна і ваколіцаў. In A. Смалянчук (Ed.), Восень 1939 г. у гістарычнай традыцььі і вуснай zісторыі. Мінск: Выдавец Зміцер Колас.

Кашталян, I. (2013). Паміж царквой і ўладай, або рэлігійная штодзённасць простага чалавека ў пасляваеннай Беларусі. In П. Рудкоўскі \& К. Колб (Eds.), Бунт у імя свабоды: Забыты беларускі ген? Варшава: Універсітэт Лазарскага.

Кашталян, I. (2015). Голад у БССР 1946-1947 гг. ва ўспамінах сведкаў часу. In А. Смалянчук (Ed.), Восень 1939 г. у гістарычнай традыцыі і вуснай гісторыі. Мінск: Выдавец Зміцер Колас.

Кісь, О. (2007). Усна історія: Становлення, проблематика, методологічні засади. Украіна модэрна, 2007(11).

Луба, В. (Еd.). (2000). Бежанства 1915 года. Białystok: "Ніва".

Луба, В. (Еd.). (2001). У новай Айчьне: Штодзённае жыциё беларусаў Беласточчыны у міжваенны перыяд. Białystok: "Ніва".

Луба, В. (Ed.). (2003). Пакаленне вайны: Штодзённае жыциё беларусаў Беласточчыны ў перыяд вайны і акупацыьі (1939-1945). Białystok: "Ніва".

Маховская, И. (2008). Исследование повседневных адаптивных практик в трансформирующемся социуме (воспоминания жителей западнобелорусского местечка о жизни “в польское время" и “при советах"). In И. Р. Такала, А. В. Голубев, И. Н. Романова, \& И. С. Маховская (Eds.), Устная история в Карелии: Выпуск IV. Карелия и Беларусь: Повседневная жизнь и культурные практики населения в 30-50-е г2. (pp. 61-73). Петрозаводск: Издательство ПетрГУ.

Пазьняк, 3., \& Шмыгалёў, Я. (1988, June 3). Курапаты - дарога сьмерці. Літаратура і мастацтва.

Пазьняк, 3. , Шмыгалёў, Я., Крывальцэвіч, М., \& Іоў, А. (1994). Курапаты: Apmыıкуль, навуковая справаздача, фотаздымкі. Мінск: “Тэхналогія”.

Пастушенко, Т. В. (2008). Устноисторические проекты на Украине: Изменение традиционных исследовательских перспектив. In M. Н. Барышников, А. В. Голубев, \& М. В. Друзин (Eds.), Проблемы отечественной истории: Источники, 
историография, исследования: Сборник научных статей. Санкт-Петербург: Нестор-История.

Портелли, А. (2003). Особенности устной истории. In M. В. Лоскутова (Ed.), Хрестоматия по устной истории. Санкт-Петербург: Издательство Европейского университета.

Прынз, Г. (2000). Вусная гісторыя. Беларускі гістарычны агляд, 7(2).

Раманава, I., \& Махоўская, І. (2009). Мір: Гісторыя мястэчка, што расказалі яго жыхары. Вільня: ЕГУ.

Романова, И. (2008). Адаптация репрессированных к жизни в обществе после возвращения из мест заключения и ссылки (по материалам интервью). In И. Р. Такала, А. В. Голубев, И. Н. Романова, \& И. С. Маховская (Eds.), Устная история в Каретии: Выпуск IV. Карелия и Беларусь: Повседневная жизнь и культурные практики населения в 30-50-е г2. (рр. 31-51). Петрозаводск: Издательство ПетрГУ.

Смалянчук, А. (2013). Палеская вёска ў стасунку да пана. In Беларуская гісторыя: Знайсиіі чалавека. Мінск: Выдавец І. П. Логвінаў.

Смалянчук, А. (Ed.). (2015). Дыскусія “Вусная гісторыя ў Беларусі: Перспектывы міждысцыплінарнага ўзаемадзення” (мадэратар Т. Вадалажская). In Восень 1939 2. y гістарычнай традыцы і вуснай гісторы

Смалянчук, А. (Ed.). (2017). Чарнобыльская аварыя і грамадства: 30 год пасля катастрофы. Мінск: Выдавец Зміцер Колас.

Смалянчук, А., \& Сідлярэвіч, А. (2000). “Добры быў пан...” Раман Скірмунт у вусных успамінах жыхароў вёскі Парэчча Пінскага раёну. Спадчьна, 2000(5-6).

Такала, И. Р., Голубев, А. В., Романова, И. Н., \& Маховская, И. С. (Eds.). (2008). Устная история в Карелии: Выпуск IV. Карелия и Беларусь: Повседневная жизнь и культурные практики населения в 30-50-е г2. Петрозаводск: Издательство ПетрГУ.

Трафімчык, А. (2015). Успаміны “заходнікаў” пра першыя савецкія выбары ў Ганцавіцкім раёне Брэсцкай вобл. In A. Смалянчук (Ed.), Восень 1939 г. у гістарычнай традыцыі і вуснай гісторыі. Мінск: Выдавец Зміцер Колас.

Улашчык, М. (1989). Была такая вёска: Гісторыка-этнаграфічны нарыс. Мінск: Мастацкая літаратура.

Хансен, I., \& Кашталян, I. (2014). Вусная гісторыя і мясцовая культура. In Гiсторыя і культура у сельскім развіциі. Мінск: "Прапілеі”.

Шаталава, В. (2008). Цені вайны: Паліцэйскія і партызаны ў памяці насельніцтва беларускай вёскі. In Homo Historicus: The Annual of Anthropological History (Vol. 1, pp. 384-389). Вільня: ЕГУ.

Шуцінене, І. (2008). Другая сусветная вайна ў калектыўнай памяці жыхароў Літвы (Ю. Унуковіч, Trans.). In Homo Historicus: The Annual of Anthropological History (Vol. 1, pp. 411-425). Вільня: ЕГУ.

Энгелькінг, Г. (2012). Паміж панам і жыдом: Заўвагі пра структуру ідэнтычнасці беларускіх калгаснікаў на рубяжы XX-XXI ст. (А. Пагарэлаг \& А. Смаленчук, Trans.). In Homo Historicus: The Annual of Anthropological History (Vol. 3, pp. 89-117). Вільня: ЕГУ. 


\section{Bibliography (Transliteration)}

Belanovich, A., \& Verameı̆chyk, H. (2011). Parlament pamiatsi: Historyi belaruskikh "ostarbaĭtaraŭ". Minsk: Mizhnarodnae hramadskae ab'iadnanne "Adukatsyia bez mezhaŭ".

Engelking, A. (2012). Pamizh panam i zhydom: Zaŭvahi pra strukturu idèntychnastsi belaruskikh kalhasnikaŭ na rubiazhy XX-XXI st. (A. Paharèlah \& A. Smalenchuk, Trans.). In Homo Historicus: The Annual of Anthropological History (Vol. 3, pp. 89-117). Vil'nia: EGU.

Filipkowski, P. (2010). Historia mówiona i wojna: Doświadczenie obozu koncentracyjnego $w$ perspektywie narracji biograficznych. Wrocław: Wydawnictwo Uniwersytetu Wrocławskiego.

Hardzienka, N. (2004). Belarusy ŭ Aŭstralii: Da historyi dyiaspary. Minsk: Medysont.

Hardzienka, N. (2010). Belarusy ŭ Vialikabrytanii. Minsk: Zhurtavanne belarusaŭ svetu Bats'kaŭshchyna.

Homo Historicus: The Annual of Anthropological History. (2008) (Vol. 1). Вільня: ЕГУ.

Homo Historicus: The Annual of Anthropological History. (2012) (Vol. 3). Вільня: ЕГУ.

Hrinchenko, H., Rebrova, I., \& Romanova, I. (2014, October 30). Usna istoriia v postradians'kykh doslidnyts'kykh praktykakh. Ukraina moderna. Retrieved August 26, 2015, from http:// uamoderna.com/md/grinchenko-rebrova-romanova-oh

Kasataia, T. (2015). Vusnaia historyia ŭ dasledavanni evanhel'skikh khrystsiian-baptystaŭ u BSSR. In A. Smalianchuk (Ed.), Vosen' 1939 h. u histarychnaĭ tradytsyi i vusnaĭ historyi. Minsk: Vydavets Zmitser Kolas.

Kasataia, T., \& Vashkevich, A. (2015). Vaŭna i mir 1939-1940 hh. va ŭspaminakh zhykharoŭ Hrodna i vakolitsaŭ. In A. Smalianchuk (Ed.), Vosen' 1939 h. u histarychnaŭ tradytsyi i vusna l historyi. Minsk: Vydavets Zmitser Kolas.

Kashtalian, I. (2015). Holad u BSSR 1946-1947 hh. va ŭspaminakh svedkaŭ chasu. In A. Smalianchuk (Ed.), Vosen' 1939 h. u histarychnă̌ tradytsyi i vusnă̌ historyi. Minsk: Vydavets Zmitser Kolas.

Kashtalian, I. (2013). Pamizh tsarkvoĭ i ŭladaŭ, abo rèlihiŭnaia shtodzionnasts' prostaha chalaveka ŭ pasliavaennaı̆ Belarusi. In P. Rudkoŭski \& K. Kolb (Eds.), Bunt u imia svabody: Zabyty belaruski hen? Varshava: Universitèt Lazarskaha.

Khansen, I., \& Kashtalian, I. (2014). Vusnaia historyia i miastsovaia kul'tura. In Historyia i kul'tura ŭ sel'skim razvitstsi. Minsk: "Prapilei".

Kis', O. (2007). Usna istoriia: Stanovlennia, problematyka, metodolohichni zasady. Ukraina moderna, 2007(11).

Kurkowska-Budzan, M. (2003). Historia zwykłych ludzi: Współczesna angielska historiografia dziejów społecznych. Kraków: Towarzystwo Wydawnicze Historia Iagellonica.

Kurkowska-Budzan, M. (2011). Informator, świadek historii, narrator - kilka wątków epistemologicznych i etycznych oral history. Wrocławski Rocznik Historii Mówionej, 1, 9-34. https://doi.org/10.26774/wrhm.5

Luba, V. (Ed.). (2000). Bezhanstva 1915 hoda. Białystok: "Niva". 
Luba, V. (Ed.). (2001). U novaĭ Ă̌chyne: Shtodzionnae zhytstsio belarusaŭ Belastochchyny $\breve{u}$ mizhvaenny peryiad. Białystok: "Niva".

Luba, V. (Ed.). (2003). Pakalenne vainy: Shtodzionnae zhytstsio belarusaŭ Belastochchyny ŭ peryiad vaĭny i akupatsyi (1939-1945). Białystok: "Niva".

Makhovskaia, I. (2008). Issledovanie povsednevnykh adaptivnykh praktik v transformiruiushchemsia sotsiume (vospominaniia zhiteleĭ zapadnobelorusskogo mestechka o zhizni “v pol'skoe vremia” i “pri sovetakh”). In I. R. Takala, A. V. Golubev, I. N. Romanova, \& I. S. Makhovskaia (Eds.), Ustnaia istoriia v Karelii: Vypusk IV. Kareliia i Belarus': Povsednevnaia zhizn' i kul'turnye praktiki naseleniia v 30-50-e gg. (pp. 61-73). Petrozavodsk: Izdatel'stvo PetrGU.

Pastushenko, T. V. (2008). Ustnoistoricheskie proekty na Ukraine: Izmenenie traditsionnykh issledovatel'skikh perspektiv. In M. N. Baryshnikov, A. V. Golubev, \& M. V. Druzin (Eds.), Problemy otechestvennoŭ istorii: Istochniki, istoriografiia, issledovaniia: Sbornik nauchnykh state ̌. Sankt-Peterburg: Nestor-Istoriia.

Paz’niak, Z., \& Shmyhalioŭ, I. (1988, June 3). Kurapaty - daroha s'mertsi. Litaratura i mastatstva.

Paz’niak, Z., Shmyhalioŭ, I., Kryval'tsėvich, M., \& Ioŭ, A. (1994). Kurapaty: Artykuly, navukovaia spravazdacha, fotazdymki. Minsk: "Tèkhnalohiia”.

Portelli, A. (2003). Osobennosti ustnoй istorii. In M. V. Loskutova (Ed.), Khrestomatiia po ustnol̆ istorii. Sankt-Peterburg: Izdatel'stvo Evropeĭskogo universiteta.

Prynz, H. (2000). Vusnaia historyia. Belaruski histarychny ahliad, 7(2).

Ramanava, I., \& Makhoŭskaia, I. (2009). Mir: Historyia miastèchka, shto raskazali iaho zhykhary. Vil'nia: EGU.

Romanova, I. (2008). Adaptatsiia repressirovannykh k zhizni v obshchestve posle vozvrashcheniia iz mest zakliucheniia i ssylki (po materialam interv'iu). In I. R. Takala, A. V. Golubev, I. N. Romanova, \& I. S. Makhovskaia (Eds.), Ustnaia istoriia v Karelii: Vypusk IV. Kareliia i Belarus': Povsednevnaia zhizn' i kul'turnye praktiki naseleniia v 30-50-e gg. (pp. 31-51). Petrozavodsk: Izdatel'stvo PetrGU.

Shatalava, V. (2008). Tseni vă̌ny: Palitsēĭskiia i partyzany ŭ pamiatsi nasel'nitstva belaruskaŭ vioski. In Homo Historicus: The Annual of Anthropological History (Vol. 1, pp. 384-389). Vil'nia: EGU.

Šutinienė I. (2008). Druhaia susvetnaia vaĭna ŭ kalektyŭnaı̆ pamiatsi zhykharoŭ Litvy (I. Unukovich, Trans.). In Homo Historicus: The Annual of Anthropological History (Vol. 1, pp. 411-425). Vil'nia: EGU.

Smalianchuk, A. (2013). Paleskaia vioska ŭ stasunku da pana. In Belaruskaia historyia: Znaĭstsi chalaveka. Minsk: Vydavets I. P. Lohvinaŭ.

Smalianchuk, A. (Ed.). (2015). Dyskusiia "Vusnaia historyia ŭ Belarusi: Perspektyvy mizhdystsyplinarnaha ŭzaemadzennia” (maderatar T. Vadalazhskaia). In Vosen' 1939 h. $u$ histarychnaĭ tradytsyi i vusnaĭ historyi. Minsk: Vydavets Zmitser Kolas.

Smalianchuk, A. (Ed.). (2017). Charnobyl'skaia avaryia i hramadstva: 30 hod paslia katastrofy. Minsk: Vydavets Zmitser Kolas.

Smalianchuk, A., \& Sidliarèvich, A. (2000). “Dobry byŭ pan...” Raman Skirmunt u vusnykh uspaminakh zhykharoŭ vioski Parèchcha Pinskaha raionu. Spadchyna, 2000(5-6). 
Smułkowa, E., \& Engelking, A. (Eds.). (2007). Pogranicza Białorusi w perspektywie interdyscyplinarnej. Warszawa: DiG.

Takala, I. R., Golubev, A. V., Romanova, I. N., \& Makhovskaia, I. S. (Eds.). (2008). Ustnaia istoriia v Karelii: Vypusk IV. Kareliia i Belarus': Povsednevnaia zhizn' i kul'turnye praktiki naseleniia v 30-50-e gg. Petrozavodsk: Izdatel'stvo PetrGU.

Trafimchyk, A. (2015). Uspaminy “zakhodnikaŭ” pra pershyia savetskiia vybary ŭ Hantsavitskim raione Brèstskaĭ vobl. In A. Smalianchuk (Ed.), Vosen’ 1939 h. u histarychnaı̆ tradytsyi i vusna historyi. Minsk: Vydavets Zmitser Kolas.

Ulashchyk, M. (1989). Byla takaia vioska: Historyka-ètnahrafichny narys. Minsk: Mastatskaia litaratura.

Valodzin, U. (2008). Pershae pakalenne menskikh “khippi” (druhaia palova 1960-kh - pershaĭ palova 1970-kh hh.). Zialiony kră, 2008(2).

Valodzin, U. (2014). Kalektyŭny zvarot studentaŭ-filosafaŭ 1981 h. Mensk.

\title{
Oral history in Belarus: Present state and development trends
}

\begin{abstract}
The oral history in Belarus has become an important line of enquiry in the humanities and a significant field of interdisciplinary dialogue. It also functions as an important research practice. Nevertheless, under the conditions of the current Belarusian historical policy, imbued with Soviet ideological dogmas, there is no prospect of transforming it into an academic discipline. At present, prospects for the development of oral history in Belarus are connected with the activity of scholarly and community NGOs. The most important of them is an online project called The Belarusian Archives of Oral History, active since 2011.
\end{abstract}

Keywords: Belarus; oral history; memory

\section{Historia mówiona na Białorusi: aktualny stan i tendencje rozwojowe}

\section{Streszczenie}

Obecnie historia mówiona na Białorusi stała się ważnym kierunkiem badań naukowych w dziedzinie nauk humanistycznych oraz obszarem dialogu interdyscyplinarnego. Funkcjonuje też jako ważna praktyka humanistyczna. Jednak w sytuacji obecnej 
polityki historycznej, wciąż przepełnionej dogmatami ideologii sowieckiej, nie ma szans na jej przekształcenie w dyscyplinę akademicką. Perspektywy rozwojowe historii mówionej na Białorusi związane są z działalnością naukowych i społecznych organizacji pozarządowych, wśród których najważniejszy jest projekt online „Białoruskie Archiwum Historii Mówionej", realizowany od 2011 roku.

Słowa kluczowe: Białoruś; historia mówiona; pamięć

Dr hab. Aliaksandr Smalianchuk, Associate Professor at the Institute of Slavic Studies, Polish Academy of Sciences; editor of a journal of anthropological history Homo Historicus (Minsk), leader of the projects "The Year 1939 in the Memory of Belarusians" and "Collectivisation in Western Belarus, 1948-1952" at the Belarusian Archives of Oral History (Minsk); author of six books and about two hundred scholarly articles, reviews, editions of historical sources, etc. His scholarly interests include ethnic relations and social and political history in the lands of the former Grand Duchy of Lithuania in the nineteenth and the twentieth centuries, collective and cultural memory studies, and oral history.

Bibliography (selected): Паміж краёвасцю і нацььянальнай ідэяй. Польскі рух на беларускіх і літоўскіх землях. 1864-1917, выданне 2-е дапоўненае [Between local identity (kraiovasts) and the national idea: The Polish movement in Belarusian and Lithuanian lands, 1864-1917], 2nd revised edition, Санкт-Петербург (Saint Petersburg) 2004; Беларуская гісторыя: знайсиі чалавека [Belarusian history: In search of a human being], Мінск (Minsk) 2013; «Краёвая ідэя» у беларускай гісторы [The idea of local identity (kraiovasts) in Belarusian history], Мінск (Minsk) 2017; Раман Скірмунт (1868-1939): жыцияпіс грамадзяніна Краюо [Raman Skirmunt (1868-1939): The life history of a citizen of The Land], Мінск (Minsk), 2018.

Correspondence: Aliaksandr Smalianchuk, Institute of Slavic Studies, Polish Academy of Sciences, Warsaw, e-mail: aleksander.smalianchuk@ispan.waw.pl

Support of the work: The study was conducted at the author's own expense.

Competing interests: No competing interests have been declared. 